(forthcoming in Journal of the History of Philosophy)

\title{
Does Kant Demand Explanations for All Synthetic A Priori Claims?
}

\author{
Colin Marshall
}

\begin{abstract}
Kant's philosophy promises explanations for various synthetic a priori claims. Yet, as several of his commentators have noted, it is hard to see how these explanations could work unless they themselves rested on unexplained synthetic a priori claims. Since Kant appears to demand explanations for all synthetic a priori claims, it would seem that his project fails on its own terms. I argue, however, that Kant holds that explanations are required only for synthetic a priori claims about (purportedly) experience-independent entities, and that his project rests on a rationalist method of reflection that justifies certain basic synthetic a priori claims.
\end{abstract}

In his Prolegomena to Any Future Metaphysics, Kant states that “[a]ll metaphysicians are ... suspended from their occupations until such a time as they will have satisfactorily answered the question: How are synthetic cognitions a priori possible?" (Prolegomena 4:278). ${ }^{1}$ In the Critique of Pure Reason, Kant describes the issue of the synthetic a priori as "[ $\mathrm{t}]$ he real problem of pure reason" (B19), and in the Critique of the Power of Judgment, as "the general problem of transcendental philosophy" (Judgment 5:289). Kant attempts to answer this question for certain synthetic a priori cognitions (e.g. those of mathematics and of natural science), and argues that no such answer can be found for others (in particular, certain claims of traditional metaphysics). It appears, then, that Kant holds that every purported synthetic a priori cognition requires an explanation, that some can be explained, and that those without explanations should be either rejected or given a merely regulative role in our thought.

Several commentators have noted that there is a puzzle about how the positive part of

\footnotetext{
${ }^{1}$ In what follows, I will use A/B pagination for references to the Critique of Pure Reason. For other works, I will give an abbreviated title along with the volume and page number from the Academy Edition. Unless otherwise noted, all translations will be from the Cambridge edition of Kant's works.
} 
Kant's project could work. ${ }^{2}$ The puzzle, which I will call the 'Regress Puzzle,' arises when we ask: If Kant demands explanations for all synthetic a priori claims, ${ }^{3}$ then how does he think a successful explanation works? Consider Kant's summary of one of his own explanations:

The problem of the present section is therefore solved. Pure mathematics, as synthetic cognition a priori, is possible only because it refers to no other objects than mere objects of the senses, the empirical intuition of which is based on a pure and indeed $a$ priori intuition (of space and time), and can be so based because this pure intuition is nothing but the mere form of sensibility, which precedes the actual appearance of objects, since it in fact first makes this appearance possible. (Prolegomena 4:283-84)

Bracketing some questions about what sort of explanation this is, ${ }^{4}$ we can see that it shares at least two general features with the other explanations Kant gives. First, Kant relies on some claims other than those he initially aims to explain. Second, his explanations are finite and noncircular, so that there must be some explanatorily basic claims. Here, the claim that "pure intuition is nothing but the mere form of sensibility," or that it "first makes this appearance possible" is where the explanation bottoms out. So a successful explanation for some purported synthetic a priori claim, by Kant's standards, consists of further claims that show why the former claim holds, where some of these latter claims receive no further explanation.

The core of the Regress Puzzle concerns the status of such basic claims. It seems that they must be a priori, since Kant states that for the critique of pure reason, "absolutely no concepts [may] enter into it that contain anything empirical" (A14/B28). ${ }^{5}$ But if they are a priori, are they analytic or synthetic? In the present case, it is hard to see how it could be analytic that

\footnotetext{
${ }^{2}$ Moore, "Kant's Idealism, 133, Bennett, Kant's Analytic, 16-17, BonJour, In Defense of Pure Reason, 24-25, and Forster, Kant and Skepticism, 64-68. In essence, this puzzle is just a sharpened version of the familiar objection that Kant's supposed solutions merely "push [...] the mystery a stage further back" (Ayer, Language, Truth, and Logic, 73).

${ }^{3}$ At various places, Kant describes the problem in terms of "judgments" ("Urteile"), "cognitions"

("Erkenntnissen"), and "propositions" ("Sätze”). Calling all these 'claims' makes the force of the puzzle clear, though I do think there are important questions here.

${ }^{4}$ While all interpreters agree that Kant's explanations are partly concerned with epistemology, there is divergence on whether these explanations are essentially psychological, and whether they rest on a metaphysically strong form of idealism. The Regress Puzzle can surface on any interpretation, so I will set these questions aside for now. My solution to the puzzle, however, will not be impartial.

${ }^{5}$ Why this is so is an interesting question - one that could be resolved only by fixing on an interpretation of Kant's idealism and epistemology. P. F. Strawson asks why we could not explain our having space and time as forms of intuition on the basis of the (empirical) claim that objects really are in space in time (cf. Strawson, "Sensibility," 72). My view is that this question forces us toward more metaphysical readings of Kant's idealism, and what I say in later sections can be taken as one stage of an argument for this view.
} 
space and time are pure intuitions or the mere form of our sensibility. ${ }^{6}$ Even if they were analytic, we would wonder how they alone could do the needed explanatory work. Roughly speaking, analytic claims are just definitional truths, ${ }^{7}$ and the synthetic a priori claims to be explained are substantive claims. No number of definitional truths could fully explain, say, why at most three lines can intersect at right angles at a point, so if Kant is relying on only analytic truths in his explanations, then he has no hope of answering his own challenge.

On the other hand, if any of the basic claims were synthetic, then Kant would not be answering his own challenge of explaining all synthetic a priori claims. Either way, it looks like Kant's framework for explaining the synthetic a priori precludes him from providing successful a explanation for any synthetic a priori claim. If so, his system is no better off than that of the metaphysicians he criticizes.

The commentators who raise this puzzle think it shows where Kant goes wrong. Michael Forster, for instance, concludes that it shows that Kant had a "failure of self-reflection." argue, however, that the interpretive puzzle can be met, and that Kant's project is fully coherent. In brief, I will argue that Kant does not think that every synthetic a priori claim requires explanation, so that his own explanations take some synthetic a priori claims as explanatorily basic. The Regress Puzzle shows only that Kant's way of advertizing his project is misleading. My argument has six stages. After considering two potential objections to the terms of the Regress Puzzle $(\S 1)$ and a direct argument for my conclusion ( $(2)$, I argue that two alternative solutions to the puzzle are unsuccessful (§3). I then present textual and philosophical grounds for my proposal $(\S 4)$. The proposal raises epistemological questions, which I address by arguing that Kant accepts a doctrine of limited mental transparency (\$5). ${ }^{9}$ I conclude by considering six potential objections (§6).

To keep the discussion manageable, I focus on the explanations in Kant's mature

\footnotetext{
${ }^{6}$ Especially because Kant admits the possibility of other forms of intuition. See A27/B43, A230-31/B283.

${ }^{7}$ In the Jäsche Logic, Kant describes analytic judgments as having the form "all x's that are $(\mathrm{a}+\mathrm{b})$ are (b)" and synthetic judgments as having the form "all x's that are (a+b) are (c)" (cf. Logic 9:111). He is clear, however, that in an analytic judgment, the predicate concept (b) might be contained in the subject concept $(a+b)$ only implicitly. Note that I take a definitional truth to be less than a definition; most analytic judgments are not definitions for Kant, since he requires that a definition lay out all the marks contained in a concept (see A727/B755).

${ }^{8}$ Forster, Kant and Skepticism, Chapter 11. Forster takes this as motivation for preferring a Hegelian approach.

${ }^{9}$ The closest thing in the literature to this part of my positive proposal is Smit, "Role of Reflection." Smit is not, however, concerned with the Regress Puzzle as such, and so does not take a stand on whether the results of the reflection he ascribes to Kant are basic synthetic a priori claims.
} 
theoretical philosophy. Other parts of Kant's system yield important clues along the way, however.

\section{Objections to the Regress Puzzle}

I begin with two potential objections to the assumptions behind the Regress Puzzle. As formulated, any solution to the Regress Puzzle will involve giving up some prima facie plausible interpretive claim, so it would be preferable if we could instead show that the puzzle rests on a mistake.

1.1. First objection: Kant is merely deducing conditions of the possibility of experience, or making an inference to the best explanation

One might object that the Regress Puzzle stems from a confusion, since all Kant aims to do is explain the conditions of the possibility of experience. Though I suspect some of Kant's readers have thought this was an adequate account of Kant's project, it alone does not answer the puzzle. Experience surely has a wide variety of conditions (metaphysical, epistemological, psychological, etc.), some of which might be knowable only a posteriori, others by analysis, and others only by non-analytic a priori insight. ${ }^{10}$ To address the puzzle, we would need to know how Kant's particular claims about the conditions for the possibility of experience were justified. The same thing holds for the view that Kant is merely making inferences to the best explanation. Inferences to the best explanation can be more or less empirically informed. They may also be guided by a priori constraints (e.g. principles favoring simplicity), and one can ask whether these constraints are analytic or synthetic. Therefore, while Kant certainly thinks that he is giving the best explanation for experience, and that he makes inferences supporting that explanation,

\footnotetext{
${ }^{10}$ Appeal to "epistemic conditions" is at the core of Henry Allison's reading of Kant (cf. Kant's Transcendental Idealism, 47). Allison's chief interest is in avoiding a metaphysical construal of Kant's project, however, and he does not explicitly address the Regress Puzzle (though his picture of epistemic conditions reflecting the nature of the mind is to some degree amenable to the below proposal).
} 
pointing this out by itself does not address the Regress Puzzle. ${ }^{11}$

This point applies even to sophisticated forms of these readings. For instance, Michael Friedman has argued persuasively that Kant's theoretical philosophy is largely aimed at explaining the philosophical foundations of Euclidean geometry and Newtonian physics. In general (and in many of its details), however, this reading does not address the Regress Puzzle. For we can ask how Kant thinks his claims about those foundations are justified. It seems unlikely, and Friedman does not suggest, that Kant's conclusions about the foundations of geometry and physics are reached simply through conceptual analysis. Nor does it seem, and nor does Friedman suggest, that Kant takes empirical facts about these disciplines' successes and then reaches his conclusions in a single abductive leap. It is much more plausible (and Friedman does suggest this ${ }^{12}$ ) that Kant brought antecedent philosophical views to bear on these sciences, and that his final views were the result of an interaction between the two. But then the Regress Puzzle remains.

To be clear: the fact that such approaches do not answer the Regress Puzzle does not show that they are mistaken, but only that we should not take them to give the complete story about Kant's explanations of the synthetic a priori.

\subsection{Second objection: Not all claims are either synthetic or analytic}

As I formulated it, the puzzle rests on the assumption that any a priori claim must be either analytic or synthetic. One could resist the puzzle, therefore, by insisting that the basic claims in Kant's explanations are neither analytic nor synthetic. ${ }^{13}$

\footnotetext{
${ }^{11}$ For a relevant discussion, see Merritt, "Analysis in the Critique of Pure Reason," 66-69. Analogous concerns apply to Avery Goldman's ingenious suggestion that the critical project begins with a merely regulative idea of the unified subject ("Critique and the Mind").

${ }^{12}$ Cf. Friedman, Exact Sciences, xiii, 136ff.

${ }^{13}$ The secondary literature contains a number of suggestions of alternative ways to classify Kant's explanations. Patricia Kitcher attempts to avoid the problem by denying that Kant aims to give "logical proofs" of synthetic a priori claims (Kitcher, Kant's Transcendental Psychology, 17-18, Kitcher, "Revisiting Kant's Epistemology," 293, 303), though for reasons I will give, I do not think this avoids the puzzle. Kenneth Westphal claims that we can not only avoid the dilemma, but do so in a way that is compatible with naturalist epistemology (Westphal, "Epistemic Reflection", 135 - I discuss his particular proposal below). More promisingly, I think, Katherine Dunlop suggested (in comments on an earlier version of this paper) that the notion of possible experience might be close enough to the
} 
An initial problem with such an approach is that Kant consistently speaks as though all judgments are either analytic or synthetic (and sometimes defines synthetic judgments as nonanalytic ones $\left.{ }^{14}\right) .{ }^{15}$ That said, Kant sometimes talks as though the analytic/synthetic distinction applies only to subject-predicate judgments (e.g. A6/B10ff), and his ways of characterizing the distinction (e.g. predicate-containment) are difficult to apply to, e.g., the hypothetical form of judgment. ${ }^{16}$ There is therefore room to wonder about whether the analytic/synthetic distinction is exhaustive. Moreover, Kant claims the "supreme principle" of synthetic judgments is: "Every object stands under the necessary conditions of the synthetic unity of the manifold of intuition in a possible experience" (A158/B197, cf. "On a discovery" 8:241). If Kant thinks it is definitive of synthetic judgments that they have a certain relation to intuition, then, in principle, there would be room for some a priori judgments that rested on neither predicate containment nor intuition, and so were neither analytic nor synthetic.

These moves do not allow us to avoid the puzzle, however. For one, many of the claims Kant makes that appear to be basic are of subject-predicate form, and do have some relation to intuition (e.g. space and time are the sole forms of our intuition). For another, though Kant states that a relation to intuition is crucial for synthetic judgments, he never includes this in his definition of 'synthetic.' Most importantly, however, the real core of Kant's question about the

concepts involved in the judgments of Kant's philosophy that it no longer counts as a "third thing," so that the judgments are not importantly distinct from analytic judgments. This may be the correct account of why Kant does not classify the basic judgments of his philosophy, though (for reasons I discuss below) it does not address the core of the puzzle.

${ }^{14}$ A7/B10-11, Prolegomena 4:266-67, Logic 24:278-29, "On a discovery," 8:245 (though see the following note), Logic 9:111. The "thought through identity" characterization of the distinction at A7/B10 also has this implication (though it is arguable whether this distinction is meant to apply beyond subject-predicate judgments). Reflexion 3043 explicitly states that all judgments are either analytic or synthetic.

${ }^{15}$ Could Kant's basic claims be something other than judgments (Urteile), cognitions (Erkenntnisse), or propositions (Sätze)? This seems unlikely, since they are certainly thoughts, and Kant never indicates it is possible to think without judging. On the other hand, Kant does make it clear that judgments concern objects (e.g. A68/B93, B14142), and if 'object' is meant in a restricted sense in those passages, then perhaps claims merely concerning the thinking subject would not count as judgments for Kant. Or perhaps one could argue that the claims are in a special class due to their independence from intuition (which Kant sometimes, but not always, claims is necessary for something to be cognition - cf. B146 and A320/B376-77). Even if this were true, however, it would not by itself explain why such claims were less problematic than (e.g.) the claims of rational psychology. At most, we would have an explanation of why Kant does not call his basic claims judgments or cognitions, not a solution to the puzzle. ${ }^{16}$ For a helpful discussion, see Proops, "Kant's Conception of Analytic Judgment." Proops points out that Kant's aim of showing the synthetic nature of judgments of mathematics, natural science, and metaphysics does not require that the analytic/synthetic distinction be exhaustive ("Kant's Conception of Analytic Judgment" 596). In the 1791 “What Real Progress?' essay, Kant states that trivially identical judgments ("a=a") should no longer be counted as analytic ("What Real Progress?", 20:322). 
synthetic a priori is this: on what basis can one make an a priori claim that is not analytic?

Consider how Kant formulates his challenge to traditional metaphysicians:

in synthetic a priori judgments this means of help [i.e. experience] is entirely lacking. If I am to go beyond the concept $\mathrm{A}$ in order to cognize another B as combined with it, what is it on which I depend and by means of which the synthesis becomes possible, since I here do not have the advantage of looking around for it in the field of experience? (A9/B12-13, cf. Prolegomena $4: 277)$

Kant's challenge is a general one: it is clear (he thinks) how we can justifiably make analytic a priori claims, but not so for any other sort of a priori claim. Regardless of what Kant calls nonanalytic a priori claims, we will face some form of the original puzzle. With that noted, in what follows I will treat the analytic/synthetic distinction as exhaustive.

2. A direct argument for basic synthetic a priori claims?

Though I think the best argument for the conclusion that Kant accepts some basic synthetic a priori claims comes from considering the Regress Puzzle, there is a more direct argument for that conclusion that is worth considering. The direct argument works simply by identifying some claims that Kant makes that are obviously (1) basic to his philosophical system, (2) a priori, and (3) not analytic.

There are at least two claims in the first Critique $^{17}$ that seem to have features (1)-(3): the principle of contradiction, and the distinction between intuitions and concepts. The case that they satisfy these features is quite strong, though not decisive.

\footnotetext{
${ }^{17}$ This point is easier to establish for the second Critique, where Kant claims that "pure reason, practical of itself, is here immediately lawgiving ... Consciousness of this fundamental law may be called a fact of reason because one cannot reason it out from antecedent data of reason ... and because it instead forces itself upon us of itself as $a$ synthetic a priori proposition that is not based on any intuition, either pure or empirical" (Practical Reason 5:31, my emphasis). Not surprisingly, many commentators have worried about the lack of argument here. Lewis White Beck writes that this looks suspiciously like "[a]n appeal to insight or intuition [that is really] a confession of failure to find an argument or premise ... and an unwillingness to surrender ... in spite of that" (Beck, Commentary, 167). The solution I propose below gives resources for a more optimistic assessment.
} 
2.1. The principle of contradiction as a basic synthetic a priori claim

Kant holds that the principle of contradiction (on one formulation: "no predicate pertains to a thing that contradicts it" (A151/B190)) is the "supreme principle" of all analytic judgments. ${ }^{18}$ He never attempts to derive the principle from anything else, and it is clear that it is a priori for him (its apriority explains the apriority of analytic judgments generally). So the principle of contradiction has features (1) and (2).

But did Kant think that the principle itself was not analytic (feature (3))? ${ }^{19} \mathrm{We}$ can imagine how an attempt to demonstrate its analyticity might go. Kant thinks the judgment that no body is unextended is analytic (Prolegomena 4:267), because the concept of body contains the concept of extension. The form of that judgment is "no $(a+b)$ is non-(b)," and it is in virtue of having this form that it is analytic. If the principle of contradiction itself is understood as "for any predicate $\mathrm{P}$, nothing that is $(\mathrm{P}+\ldots)$ is non- $(\mathrm{P}))$," then it might seem to have the characteristic form of an analytic judgment. ${ }^{20}$

There are at least four pieces of evidence that Kant did not see the principle as analytic, however. First, the principle does not quite meet the form-based criterion of analyticity. The principle of contradiction has a one more quantifier than typical negative analytic judgments do, which ranges over predicates. That distinguishes it from a judgment like "no unlearned person is learned" (A153/B192), whose only quantifier ranges over things. This extra quantifier means that it is not an instance of the same form, so if all negative analytic judgments have the "no $(a+b)$ is

\footnotetext{
${ }^{18}$ This contrasts with his view in the 1755 New Elucidation, where Kant claims that the supreme principle is the "twin principle of identity" ("everything that is, is and everything that is not, is not" - see New Elucidation 1:388ff.), and that the principle of contradiction is "nothing but the definition of the impossible" (ibid. 1:391). Kant appears to abandon both of these claims in his mature philosophy.

${ }^{19}$ There would be a question here even if the principle were analytic. If the principle were analytic, then it would be self-supporting. But there are other self- supporting principles we do not accept (e.g. "Every judgment with seven words is true"), so there would be a non-trivial question of with what right we accept one such principle but not the others. Further, there would be a question of how we come to know that a given claim is analytic or synthetic. Consider the claim that $7+5=12$ is a synthetic judgment. That second-order judgment is surely not analytic in Kant's sense, though Kant thinks it is "incontrovertibly certain" (Prolegomena 4:268).

${ }^{20}$ Alternatively, one might think that the principle must be analytic because it is what defines which judgments are analytic. Yet even if the principle did define analyticity (for reasons to deny that, see Proops, "Kant's Conception of Analytic Judgment," 603), that would not show that it was itself analytic. Both analytic and non-analytic principles can capture the essence of some class of things and thereby distinguish them from other things. Kant's view that general logic concerns analytic relations (e.g. A76/B102) likewise does not entail that its fundamental principle is an analytic one.
} 
non-(b)" form, the principle of contradiction is not an analytic judgment.

Second, though Leibniz and Wolff did not have Kant's exact notion of analyticity, their notion of concept-containment (and in Leibniz, finite vs. infinite analyses) is closely enough related that we can see that they would deny that the principle was analytic. While they held that the principle of contradiction was self-evident, they did not regard it as being true because of concept containment. Leibniz calls it a "primitive axiom," 21 and says that "one should work to find ways of proving all axioms except primary ones, ${ }^{22}$ where proof is the distinguishing features of analyses. Wolff describes our understanding of the principle as arising from the apparently psychological fact that we cannot judge something both to be and not to be. ${ }^{23}$ Since Kant inherits much of the Leibnizian view of logic, we have reason to think that he does not see the principle as analytic.

Third, Kant claims that "[a]ll analytic judgments rest entirely [beruhen gänzlich] on the principle of contradiction" (Prolegomena 4:267). Like the English word 'rest,' 'beruhen' is irreflexive. So the principle of contradiction could not rest on itself, and so could not be analytic.

Finally, in his 1800 introduction to the volume of Kant's logic he edited, Gottlob Jäsche notes that while some philosophers (such as Fichte and Schelling) thought that the principle of contradiction required some further ground, Kant thinks the principle "has its evidence in itself" (Logic 5:6). Jäsche concludes that whose view about this is correct is open. This would be a strange way of putting the matter if Jäsche knew that Kant believed he had a straightforward proof for the principle (analytic claims have straightforward proofs ${ }^{24}$ ). Jäsche's description would be much more apt if he thought that this was a fair disagreement where Kant did not have much more to say (much less a simple, supposedly decisive argument for his view). Of course, Jäsche may not have understood every aspect of Kant's thought, but since it is the main topic he addresses in his introduction, it is likely that Jäsche discussed this point with Kant himself.

There is, therefore, significant evidence that Kant thinks the principle of contradiction

\footnotetext{
${ }^{21}$ Leibniz, Philosophical Essays, 31.

${ }^{22}$ Leibniz, New Essays on Human Understanding, 75.

${ }^{23}$ Cf. Wolff, Vernünftige Gedancken, §10, and Wolff, Philosophia prima, §27. For a useful discussion, see Lanier Anderson, "Wolffian Paradigm". Anderson raises the question of whether the principle of modus ponens would count as analytic for Kant, and suggests that Kant should have taken it as non-analytic ("Wolffian Paradigm", 4546).

${ }^{24}$ More specifically: if one knows a claim is analytic, then one can provide a straightforward proof. That is not to say that figuring out whether a claim is analytic is always easy (cf. A727/B755ff.).
} 
was synthetic. If so, then Kant has at least one basic synthetic a priori claim.

2.2. The principle of the distinctness of concepts vs. intuitions as a basic synthetic a priori claim

Another claim that seems to satisfy features (1)-(3) is Kant's insistence that our cognition involves two fundamentally different constituents: concepts and intuitions. More specifically, consider Kant's claim that no mix of concepts can amount to an intuition, and vice-versa. This claim appears at the beginning of the Transcendental Analytic (cf. A50/B74ff.), and plays a key role throughout the Transcendental Analytic. ${ }^{25}$ Kant surely knew that this was a substantive claim, since many of his predecessors attempted to explain all our experience using a single species of representation (cf. his criticism of Leibniz and Locke at A271/B327). Given that, Kant presumably would have provided an explanation or defense of his claim if he had one. Yet Kant never offers an explicit defense, ${ }^{26}$ so this claim has feature (1). Further, it is hard to see how that claim could be a posteriori, especially given its modal force (perhaps the existence of concepts and intuitions is a posteriori, but that is another matter). So the claim also seems to satisfy (2). Finally, Kant derives very substantive conclusions quite directly from the distinction (the criticisms of Locke and Leibniz are especially clear cases), implying that he does not see it as analytic - which means it has feature (3). ${ }^{27}$

\footnotetext{
${ }^{25}$ Kant also relies on the distinction in the Prolegomena, without offering any defense of it (cf. Prolegomena 4:280ff.). A similar thing happens in the Inaugural Dissertation (where Kant specifically targets Wolff for not appreciating the distinction), though there Kant implies that the distinction was recognized in antiquity (cf. Dissertation 2:395). Henry Allison, who makes this distinction central to his reading of Kant, says that "Kant assumes rather than argues for the discursivity thesis, even while insisting that it is not the only conceivable kind of cognition. Like so much else in his philosophy, he seems to regard it as an ultimate 'fact,' for which no explanation is either possible or necessary" (Idealism and Freedom, 6). Michael Friedman has argued that the distinction is tied to Kant's insight into the proof-structure of traditional Euclidean geometry. But Friedman is cautious about saying that Kant thinks the distinction is justified in the first place by reflection on geometry (Cf. Friedman, Exact Sciences, 96).

${ }^{26}$ His discussion of transcendental reflection at the beginning of the Amphiboly chapter of the Critique (A261/B317ff.) is clearly relevant, though that chapters seems to assume that the concept/intuition distinction is already in place. A similar point may apply to the analytic/synthetic distinction. In the Prolegomena, Kant claims that to recognize this distinction, "[o]ne must first come to [it] oneself through one's own reflection" (Prolegomena 4:270). Daniel Kolb claims that the distinction is based on transcendental reflection, as opposed to anything like direct insight into the mind, but his description of transcendental reflection does not rule out it being a form of direct insight (Kolb, "Thought and Intuition in Kant's Critical System").

${ }^{27}$ Of course, Kant does offer definitions of 'concept' and 'intuition' that suggest their fundamental distinctness (e.g.
} 
Though this evidence is quite strong, one could insist that the concept/intuition distinction is analytic, in that it comes out of a careful analysis of the concept of experience (Kant does claim that intuitions and concepts are jointly necessary for experience (e.g. B147)). Alternatively, one could insist that the distinction is derived from experience, though in a special way. To see why neither proposal is plausible, we need to look at two general approaches to resolving Regress Puzzle: the view that Kant's explanations are entirely analytic, and the view that they have an a posteriori component.

3. An argument by elimination: against purely analytic and partly a posteriori readings

If we accept its terms, there are three ways of resolving the Regress Puzzle. We could assert that: (a) Kant's explanations are purely analytic, (b) some of Kant's explanatory claims are a posteriori, or (c) some of Kant's basic claims are synthetic a priori. (b) and (c) are consistent, but it would be surprising if both were true. (b) amounts to an empiricist reading of Kant, whereas (c) amounts to a more rationalist reading. In this section, I argue that interpretations (a) and (b) face serious objections. The following section will show that the problems that face (c) are less serious, and that (c) has significant textual and intuitive support.

\subsection{Against a pure analytic reading}

The attraction of interpretation (a) is that it makes the methodology of the Critique straightforward. On this reading, "Kant attempts to show what the limiting features must be of any notion of experience which we can make intelligible to ourselves." ${ }^{28}$ For instance, the claim

A320/B376), but that would not provide a basis for objecting to Leibniz or Locke (who could each reply that one of the definitions did not correspond to anything). Normal empirical observation of our representations (as Kant understood it) could not establish this modally strong claim either - after all, Leibniz would surely respond that our finite minds are not able to fully understand how a given perception was built out of judgments.

${ }^{28}$ Strawson, Bounds, 24. Jonathan Bennett similarly claims that Kant's basic claims are "unobvious but analytic" (Kant's Analytic, 42). More recently, Georges Dicker has argued that such an approach "maximizes the philosophical interest and plausibility" of Kant's constructive project, though he concedes that "I would not claim 
about the distinction between intuitions and concepts might be read as an elliptical analytic judgment along the lines of: according to our concept of experience, there are two fundamentally different types of representations.

The objections to this sort of reading are familiar enough that I will move through them quickly. Kant explicitly states that "synthetic judgments ... can by no means arise solely from the principle of analysis" (Prolegomena. 4:267). ${ }^{29}$ Even the best known proponent of this reading, P. F. Strawson, held that such analysis was at most one aspect of Kant's project. Further, the sort of arguments Strawson articulated were not clearly analytic in Kant's sense discovering "the limiting features of any notion of experience we can make intelligible to ourselves" sounds like more than just unpacking the constituent parts of some concept (something also true of interpretations of Kant as "regressing" from experience ${ }^{30}$ ). After all, merely showing that something is a feature of our current concept of experience is a long ways from showing that it is a necessary feature of any notion of experience. ${ }^{31}$

\subsection{Against a partly empirical reading}

Interpretation (b) is the view that Kant's explanations include some a posteriori claims. ${ }^{32}$

\footnotetext{
that this interpretation is easily reconcilable with everything Kant says" (Dicker, Kant's Theory, 48).

${ }^{29}$ Later in the same passage, Kant is more specific: "a synthetic proposition can of course be discerned in accordance with the principle of contradiction, but only insofar as another synthetic proposition is presupposed from which the first can be deduced, never however in itself' (Prolegomena 4:268). Kant's objections to purely analytic approaches to philosophy go back at least to the 1763 Inquiry (cf. Inquiry 2:285). See also A65-66/B90-91, where Kant contrasts his project of analyzing the faculty of understanding with the more common project of analyzing concepts. Confusingly, in the B Deduction Kant seems to state that an analytic proposition entails that a synthesis is necessary (B135), but we are not forced to interpret this as deriving a synthetic claim from an analytic one (contrary to Guyer, "The Transcendental Deduction of the Categories," 139).

${ }^{30}$ For this sort of worry, see Stroud, "The synthetic a priori in Strawson's Kantianism." The classic statement of the regressive interpretation is Ameriks, "Regressive Argument." See also the introduction to Ameriks, Interpreting Kant's Critiques.

${ }^{31}$ Ermanno Bencivenga attempts to revive the Strawsonian approach, though he admits it yields an unattractive picture of Kant's philosophy (Bencivenga, Kant's Copernican Revolution). Derk Pereboom offers an extended critique of the interpretation in Pereboom, "Kant on Justification."

${ }^{32}$ This interpretive line is more prevalent than is often realized. For instance, Patricia Kitcher suggests that Kant proceeds "by taking the best available information about what cognitive tasks we can perform and the best available evidence about the deliverance of our senses, and trying to determine whether any non-empirical features were required and, if so, whether this contribution could somehow be defended" (Kitcher, "Revisiting Kant's Epistemology," 300). Appeal to "the best available evidence" amounts to saying that Kant's starting point was partly
} 
There is significant evidence against this reading, which is familiar to most of Kant's readers. The most obvious textual evidence is Kant's way of contrasting his approach with that of the empiricists (e.g. A85/B117ff., Prolegomena 4:257). That contrast is based on Kant's view that the content of empirical claims is too limited to ground the relevant synthetic claims. For Kant, experience itself only yields cognition of contingent facts, and the claims in question concern necessities (cf. B3-4), so a posteriori claims could hardly explain the latter.

Nonetheless, Derk Pereboom has shown that this approach cannot be dismissed so quickly. Pereboom points out that there are two things we might be asking about concerning the apriority of Kant's explanations. On the one hand, we might be asking what those explanations say about the genesis of certain representations. In that case, an explanation is counted as a priori just in case it traces that genesis back to non-experiential sources. On the other hand, we might be asking whether the claims involved in those explanations (the claims about the genesis of certain representations) are justified on the basis of something experiential. These can come apart: we might well have empirical justification for claiming that some representation is nonempirical in origin.

Most of Kant's claims about the apriority of his explanations focus on the genetic issue: what Kant primarily insists on is that our representations of space, time, cause, etc., do not derive from experience, not that he, Kant, arrived at this account of our representations through nonempirical means. On Pereboom's reading (which builds on Philip Kitcher, "A Priori Knowledge"), Kant's claims are nevertheless "a priori," in the sense that they are "based only on information derivable given any possible human experience." ${ }^{, 33}$ According to Pereboom, it is because Kant turns to experience that he is able to justifiably make the basic synthetic claims that form the core of his explanations.

Though the textual basis for reading Kant's talk of apriority in this latter way is limited, ${ }^{34}$

empirical.

${ }^{33}$ Pereboom, "Kant on Justification", 40, 46.

${ }^{34}$ The Pereboom/Kitcher reading is hard to reconcile with passages such as: "we shall understand by a priori knowledge, not knowledge independent of this or that experience, but knowledge absolutely independent of all experience" (B2-3), and with Kant's systematic way of carefully separating partly empirical projects from purely a priori projects (see, for instance, Metaphysical Foundations 4:482). Pereboom tries to marshal some support for the interpretation by suggesting that Kant's talk of basing a priori judgments on "possible experience in general" (e.g. A158/B197) means that some a priori judgments can be based on an experience, so long as only the general features of that experience are relevant (Pereboom, "Kant on Justification", 38). This reading seems forced to me, but I think 
Pereboom's version of (b) is a better interpretive response to the puzzle than (a). ${ }^{35}$ On closer examination, however, it becomes unclear how charitable this approach really is. On Pereboom's reading, Kant thinks he can justify the basic claims of his philosophy via any particular experience. But it is not clear how this could work. Consider his claims that space and time are our only possible forms of intuition, or that the only possible forms of judgment we have are those listed in Kant's table (A70/B95). What sort of experience would give us sufficient justification for such claims? A given experience with spatiotemporal structure, involving some forms of judgment, would not get us very far. Perhaps a sizeable accumulation of experiences could yield inductive support for these, but Kant nowhere suggests that his project has an inductive basis. More than that, "only possible" claims sound like statements about necessities, and Kant explicitly denies that claims about necessity can be justified a posteriori (e.g. A1, B3). If Kant's basic claims about the mind are supposed to rest on something empirical in the sense that Pereboom describes, then Kant's understanding of justification is implausible, and perhaps incoherent. $^{36}$

These costs for (a) and (b) might be acceptable if the costs for (c) were even greater. ${ }^{37} \mathrm{I}$ now turn to arguing that the problems with (c) are comparatively small, and that the textual reasons for accepting it are substantial.

\footnotetext{
the success or failure of Pereboom's approach turns more on philosophical issues than on textual ones. That said, some of the motivations he describes in Pereboom, "Is Kant's Transcendental Philosophy Inconsistent?" are amenable to the approach I take below (in particular, tying the issue of the synthetic a priori to that of modest selfknowledge).

${ }^{35}$ The best textual support for Pereboom's interpretation may be a passage he does not cite from the second Critique: "all human insight is at an end as soon as we have arrived at basic powers or basic faculties; for there is nothing through which their possibility can be conceived, and yet it may not be invented and assumed at one's discretion. Therefore, in the theoretical use of reason only experience can justify us in assuming them. But this substitute, adducing empirical proofs in place of a deduction from sources of cognition a priori, is also denied us here with respect to the pure practical faculty of reason. For, whatever needs to draw the evidence for its reality from experience must be dependent for the grounds of its possibility upon principles of experience" (Practical Reason 5:46-47, my emphasis). This passage is problematic for any interpretation, however, since, on its most natural reading, it implies that all the faculties for theoretical cognition have a posteriori grounds for their possibility which is clearly not Kant's view.

${ }^{36}$ Pereboom is aware of such issues, and elsewhere suggests that at least some of Kant's arguments should be supplemented with stronger claims from empirical psychology (cf. Pereboom, "Self-Understanding in Kant's Transcendental Deduction").

${ }^{37}$ This seems to be part of Pereboom's motivation. Cf. Pereboom, "Kant on Justification," 41.
} 


\section{In favor of basic synthetic a priori claims}

On interpretations (a) and (b), Kant's project would be incoherent by his own standards. Kant explicitly denies that a synthetic a priori claim could be justified either merely by analytic claims or through analytic claims plus a posteriori claims. That concern, however, does not apply to (c). If Kant accepted some basic synthetic a priori claims, he could well offer internally coherent explanations of the claims of mathematics and natural science.

The primary objection to (c) is that, on the most natural reading of the text, Kant demands an explanation for all synthetic a priori claims. His reason for this seems clear enough: synthetic claims amplify our cognition (cf. A7/B11), and amplification is not free. Experience can provide such amplification, but it is not obvious how we could get amplified cognition without experience. On these terms, a synthetic a priori claim like "space and time are our only forms of intuition" would be at least as mysterious as a claim of geometry, so if Kant explains the latter by means of the former, he is making no real progress. Lack of progress is a different problem from incoherence, but a problem nonetheless.

I will respond to this worry in two steps. The first step is to show that (c) has a large amount of textual support - enough support to make us wonder whether Kant really is challenging all synthetic a priori claims. The second step is to make sense of what Kant's project would be on my proposed understanding.

\subsection{Textual support}

In a number of passages, Kant seems to explicitly state that he is relying on substantive (i.e. non-analytic) claims about the mind in his explanations. Here, I consider three such passages. ${ }^{38}$

The first passage comes from the Transcendental Deduction of the Categories, where Kant states that,

\footnotetext{
${ }^{38}$ See also Axii-xiv (discussed below), Bxiii, A65/B90, A125-26, A367, A707/B735 and Metaphysics 29:786.
} 
for the peculiarity of our understanding, that it is able to bring about the unity of apperception a priori only by means of the categories and only through precisely this kind and number of them, a further ground may be offered just as little as one can be offered for why we have precisely these and no other functions for judgment or for why space and time are the sole forms of our possible intuition. (B145-46, cf. Prolegomena $4: 318)$

Here, Kant effectively asserts that there is no explanation available to us for three claims: (i) that the unity of apperception can be brought about only by means of the categories, (ii) that we have all and only the functions of judgment described in Kant's table of the forms of judgment $(\mathrm{A} 70 / \mathrm{B} 95)^{39}$ and (iii) that space and time are our only forms of intuition. ${ }^{40}$ These are claims that play key roles in Kant's explanations of the claims of mathematics and natural science. As we will see, there are other passages that reinforce the impression that (ii) and (iii) are meant to be basic claims in Kant's explanations. Kant's statement that (i) is basic is more surprising, however, for (i) sounds like the conclusion of the Deduction (cf. A129, B168-69). The context of the passage, however, suggests that what is basic is that we have a discursive understanding instead of a divine understanding, where the latter would not require the categories for its operation (this is the emphasis of the two sentences preceding the quoted passage, and is a point Kant emphasizes throughout the chapter). ${ }^{41}$ It is plausible that this claim is basic to the Deduction.

It would be very misleading of Kant to say that no further ground could be offered for these claims if any of them were analytic, since analytic claims are easily explained. Moreover, Kant certainly regards these claims as a priori. We therefore appear to have at least three basic synthetic a priori claims.

\footnotetext{
${ }^{39}$ This passage challenges the motivation behind the attempts of Klaus Reich and others (e.g. Reich, Completeness) to explain the table of judgment (though the suggestion I make below insulates Kant from criticisms such as those in Forster, Kant and Skepticism, 70ff.). It does not, however, challenge the idea that Kant himself might have figured out the table of judgment on the basis of principles he thought the categories explained (cf. Longuenesse, Capacity to Judge, 357). We might be able to explain how, as a matter of intellectual history, Kant reached his views about the basic claims; all that is ruled out are interpretations which aim to find some more fundamental claim from which these claims are derived.

${ }^{40}$ See Dissertation 4:409-10 for an example of what such an explanation would look like.

${ }^{41}$ To be sure, Kant makes other claims about the primacy of apperception. For instance, in the A Deduction, Kant states that "[the] synthetic proposition that every different empirical consciousness must be combined into a single self-consciousness is the absolutely first and synthetic principle of our thinking in general" (A117n., cf. B136ff.). I avoid putting too much weight on such passages because the 'first' here may indicate non-explanatory normative priority.
} 
Kant makes a similar statement in the Preamble to the Prolegomena, where he describes the distinctive methodology of the Critique:

In the Critique of Pure Reason I worked on this question ["Is metaphysics possible at all?'] synthetically, namely by inquiring within pure reason itself, and seeking to determine within this source both the elements and the laws of its pure use, according to principles. This work is difficult and requires a resolute reader to think himself little by little into a system that takes no foundation as given except reason itself, and that therefore tries to develop cognition out of its original seeds without relying on any fact $[\text { Factum }]^{42}$ whatever. (Prolegomena 4:274)

Here, Kant talks about the starting point of his explanations: the faculty (not the concept!) of reason (cf. A247/B303). 'Reason' here describes all our pure faculties, not just the capacity described in the Transcendental Dialectic (cf. A835/B863). While Kant does not tell us what the claims were from which his explanations preceded, it is clear that they concerned the nature of our mind. Kant asserts that he took reason alone as his "given foundation." It is hard to make sense of what that would amount to if it were not a matter of basic synthetic a priori claims.

The third passage comes from the B Introduction:

[the critique of reason] cannot be terribly extensive, for it does not deal with objects of reason ... but merely with [reason] itself, with problems that spring entirely from its own womb, and that are not set before it by the nature of things that are distinct from it but through its own nature; so that, once it has become completely familiar with its own capacity in regard to the objects that may come before it in experience, then it must become easy to determine, completely and securely, the domain and the bounds of its attempted use (B23)

Kant states that the critique of reason deals merely with reason itself ('reason' meaning the same thing here as before), and that it is only because the critique becomes "completely familiar" with the nature of that capacity that it is able to determine the "domain and bounds" of its use. This passage appears in a section of the Introduction entitled "The General Problem of Pure Reason,"

\footnotetext{
${ }^{42}$ There is, of course, the "fact of reason" from the second Critique. Kant uses 'factum' twice in the first Critique. At A85/B117, 'factum' describes the sources of the development of a concept that one would discuss in an empirical deduction of that concept (in contrast to a transcendental deduction). At B128, 'factum' describes the reality of our possession of the synthetic a priori cognition of pure mathematics and general natural science. This latter use seems to be effectively the same as the use in the Prolegomena. So Kant is not saying that he makes use of no facts (in our sense of 'facts') in the Critique's explanations.
} 
which Kant identifies as the question of how synthetic a priori judgments are possible. The explanation he alludes to here must be the explanation of the synthetic a priori.

These passages strongly favor interpretation (c) over (a) and (b), and neither of those interpretations has comparable textual support. I suspect that most interpreters have read such passages non-literally, however, since they have thought that the literal reading would render Kant's project unintelligible or too unattractive. ${ }^{43}$ My next task, therefore, is explaining how we could make sense of Kant's project if involved explanatorily basic synthetic a priori claims.

One point is worth noting here. The above passages tell against thinking that Kant reaches his claims about the fundamental structure of the mind simply via an inference to the best explanation. ${ }^{44}$ Such an inference would be a "further ground" for such claims. While I suspect such inferences play a role elsewhere in Kant's philosophy (cf. the analytic method of the Prolegomena), the textual evidence suggests that is not the right story here.

\subsection{Intuitive support}

The interest of explaining all synthetic a priori claims is clear enough, but we might wonder whether Kant's project would have philosophical value if it were aiming for less than that. While my proposal ultimately makes Kant's methodology close to that of certain rationalists, it does not make his project uninteresting.

The three synthetic a priori claims in the above passage from B145-46 have something in common: they concern what Kant sees as the essential representational structures of our minds. The other two passages confirmed this. ${ }^{45}$ Moreover, the sort of synthetic a priori claims that Kant

\footnotetext{
${ }^{43}$ Nietzsche takes the literal reading and happily endorses the negative implications for Kant's project: “'How are synthetic judgments a priori possible?' Kant asked himself - and what really is his answer? 'By virtue of a faculty [Vermöge eines Vermögens]' - but unfortunately not in five words ... But is that - an answer? An explanation? Or is it not rather merely a repetition of the question? How does opium induce sleep? 'By virtue of a faculty,' namely the virtus dormitiva, replies the doctor in Molière" (Beyond Good and Evil, §11).

${ }^{44}$ For instance, Andrew Brook asserts that inference to the best explanation is the core of Kant's methodology (Brook, "Kant's View of the Mind and Consciousness of Self"). Rosenberg, Transcendental Arguments Revisited" is a classic statement of this reading.

${ }^{45}$ This is also true of the two candidates for basic synthetic a priori claims I mentioned in the first section: the distinction between concepts and intuitions, and (somewhat less clearly) the principle of contradiction. While one could formulate the principle of contradiction as being about facts or properties, Kant quite consistently formulates it
} 
sets out to explain (e.g. that the angles of any triangle add up to $180^{\circ}$, or that all events in the world have causes) lack this feature, at least as they are commonly understood. So it looks like the general structure of Kant's explanations is as follows: synthetic a priori claims about our minds' representational structures are used to explain synthetic a priori claims about (purportedly) representation-independent objects. ${ }^{46}$

Thought of in these terms, we can see the intuitive force behind the project. What is mysterious is how we could have synthetic a priori knowledge about representation-independent things. For synthetic knowledge is substantive, and it is mysterious how we could gain substantive knowledge about representation-independent things without experiencing them. ${ }^{47}$ In other words, when we are confined to the realm of the a priori, we seem to be cut off from representation-independent objects, and so it is hard to see how we could have any substantive knowledge about them. Call this the 'Distance Problem.' 48

Unlike general puzzlement about the synthetic a priori, this mystery does not arise for substantive a priori knowledge about our minds' representational structures; being confined to the realm of the a priori does not itself distance us from our own representational capacities. One class of synthetic a priori claims about the mind, therefore, is in one important respect less mysterious than synthetic a priori claims about (purportedly) representation-independent objects,

in terms of representations (e.g. "no predicate pertains to a thing that contradicts it" (A151/B190)). Contrary to what Kitcher, "Revisiting Kant's Epistemology," 306 suggests, this shows that Kant relies on more than "extremely moderate" claims about human psychology.

${ }^{46}$ Though they do not tie it to the issue of the synthetic a priori, other commentators have in effect claimed that this is the shape of Kant's project (e.g. Westphal, "Epistemic Reflection," 139). I say 'representation-independent' instead of 'mind-independent' because at least one type of claim Kant is suspicious of concerns the simplicity of the soul (which would be representation-independent, but, since souls are minds, not mind-independent).

${ }^{47}$ This is a natural way to read Kant's concern in the February 21, 1772 letter to Marcus Herz (cf. Correspondence 10:129-132). In fact, this seems to stem from a more general concern that includes both a priori and a posteriori cognition. As Kant says: "If we let outer objects count as things in themselves, then it is absolutely impossible to comprehend how we are to acquire cognition of their reality outside us, since we base this merely on the representation, which is in us" (A378). Strikingly, at least one of Kant's successors seems to take the problem of the synthetic a priori to just be a problem of distance and representation: Fichte states that the question "How are synthetic judgments a priori possible?" is "the same question" as "How do we come to assume that something external to us corresponds to the representations in us?" (Fichte, Foundations, 87 - see Lee, "The Synthetic A Priori in Kant and German Idealism" for discussion).

${ }^{48}$ This is a problem with contemporary resonance. For instance, Michael Devitt rhetorically asks "[w]hat sort of link could there be between the mind/brain and the external world, other than via experience, that would make states of the mind/brain likely to be true about the world? What non-experiential link to reality could support insights into its necessary character?" (Devitt, "There is No A Priori," 114). See also Barry Stroud's suspicion of transcendental arguments that claim to cross "a bridge of necessity" between psychological facts and external things (Stroud, "Kantian Arguments," 159). 
and it is clear that the project of using the former to explain the latter could be of great philosophical interest. $^{49}$

The fact that such a project can be motivated by the Distance Problem does not mean that it is unproblematic. In particular, the picture remains somewhat mysterious so long as we are told nothing positive about our justification for the basic claims. Kant may hold that no deeper explanation can be given for the explanatorily basic claims, but he would not make those claims if he did not think that they had some positive epistemological status. Surely Kant does not think he is guessing about our pure faculties. Put slightly differently, we might ask whether, for the basic claims, there is a "third thing" (cf. A155/B194) that provides the ground for connecting the relevant concepts, and if there is no such third thing, how Kant thinks he reaches those claims. This is the topic of the next section.

Before going on, I should note that nothing I have said has shown that Kant's only basic synthetic a priori claims concern the mind's representational structures. ${ }^{50}$ Whether he does so would have to be determined on a case-by-case consideration of his explanations, though other basic claims we find should make us ask how well the Regress Puzzle can be resolved.

\section{Short-Range Rationalist Reflection}

Other commentators have noted that Kant's system seems to bottom out in claims about the mind, and have concluded that Kant simply has nothing more to say. Lewis White Beck, for instance, concludes that Kant "has no explicit theory of how we come to know of the operations

\footnotetext{
${ }^{49}$ Kant's ethics and aesthetics are also easily understood as being motivated by the Distance Problem. In the former, Kant explains duty, rightness, goodness, etc. by appeal to practical reason. In the latter, he explains beauty in terms of the nature of our power of judgment (cf. Judgment 5:289-90).

${ }^{50}$ The most important question here, I think, is about the claim that the objects of experience are mere appearances. Whether this claim is about the mind, whether it is basic, and how in need of justification it is are questions that hinge on how we read Kant's idealism. Less problematically (at least in terms of the Distance Problem and the Regress Puzzle): many of Kant's explanations seem based on a supposition about the possibility of experience, which is why many of Kant's conclusions have a conditional form (e.g. "Experience is possible only through the representation of a necessary connection of perceptions" (B218) - which does not claim that experience is actual). Cf. A783/B811. Kant's claims about our basic faculties are not given as suppositions or conditionals, and so cannot be understood as suppositional premises or conclusions of conditional proofs.
} 
and faculties or abilities of the mind." ${ }^{, 51}$ A lack of any theory on this point would be disturbing, especially if Kant's explanations of the synthetic a priori are based in claims about the mind. I believe, however, that Kant does have something more to say, and says it explicitly. The "something more" is not an explanation, in that it does not consist of further claims that show why some synthetic a priori claim holds. Rather, Kant has a view about how he (and we) can grasp the basic claims, in a justified way. ${ }^{52}$

We get a hint about this view in the A Preface. After claiming that "I have succeeded in removing all those errors that have so far put reason into dissension with itself in its nonexperiential use" (Axii), Kant clarifies how he accomplished the task: "I have to do merely with reason itself and its pure thinking; to gain exhaustive acquaintance [ausführlicher Kenntnis] with them I need not seek far beyond myself, because it is in myself that I encounter them" (Axiv). ${ }^{53}$ Kant here states that he came to the relevant claims about the mind by becoming "exhaustively acquainted" with reason and pure thinking, where this was possible because he did not have to go "beyond himself." The implication is that he takes himself to have some sort of direct access to certain features of his mind. If we have such access to our minds, and if facts about our minds can explain our knowledge of (purportedly) representation-independent entities, then the Distance Problem could be solved.

The textual case for such a reading is very strong. In particular, there are strong grounds for thinking that Kant believes he has a method for reaching synthetic a priori claims about the mind. It is not a method that relies on some further claim - rather, it is a method of "looking" into the mind.

Kant refers to the method in question in various places in the first Critique, but his most explicit description of it comes in $\$ 40$ of the third Critique. The context is Kant's account of how, in an aesthetic judgment, one's expectation that others will agree with his or her judgment is based on recognition of common features of their representational capacities. This recognition involves an a priori ability to distinguish the subjective (contingent/individual) from the

\footnotetext{
${ }^{51}$ Beck, Essays on Kant and Hume, 33. See also Beiser, Fate of Reason, 7 and Waxman, Kant's Model, 290.

${ }^{52}$ Compare: a natural view is that we can know we are in pain (by feeling it) without having any explanation of why we are in pain.

${ }^{53}$ Forster takes his passage as claiming "a Cartesian self-transparency of the mind" that "is indefensible within the framework of the critical philosophy” (Forster, Kant and Skepticism, 133).
} 
objective (necessary/universal) features of the mind, which Kant here calls the common sense (sensus communis - not to be confused with gemeiner Menschenverstand (cf. Prolegomena $4: 259,4: 369))$. He describes this ability in quite general terms, saying that it is

a faculty for judging that in its reflection takes account (a priori) of everyone else's way of representing in thought, in order as it were to hold its judgment up to human reason as a whole and thereby avoid the illusion which, from subjective private conditions that could easily be held to be objective, would have a detrimental influence on the judgment. (Judgment 5:293) ${ }^{54}$

Though Kant's main concern here is with aesthetic judgments, he talks of considering "human reason as a whole." So it would appear that this is an ability that applies quite generally. What is especially revealing is how he describes the exercise of this ability:

this happens by one holding his judgment up not so much to the actual as to the merely possible judgments of others, and putting himself into the position of everyone else, merely by abstracting from the limitations that contingently attach to our own judging; which is in turn accomplished by leaving out as far as possible everything in one's representational state that is matter, i.e., sensation, and attending solely to the formal peculiarities of his representation or his representational state (Judgment 5:294)

Here is the method, then. We take a certain representational state, "leave out as far as possible" all the matter, and attend to its "formal peculiarities." This is not an inductive method. Instead, it looks like Kant thinks we can perform this method on a single representational state and thereby come to see what the objective representational features of our minds are, that is, the features of our minds that are common to all rational beings. These are the features Kant sometimes calls essential (cf. A45/B62, A126, A165/B206, Prolegomena 4:287, 4:308, Metaphysical Foundations 4:472). The method thus justifies us in very strong claims (stronger, say, than the

\footnotetext{
${ }^{54}$ See Palmer, "On the Necessity of Beauty" for an argument that there is a single common sense with both aesthetic and cognitive uses (though Palmer implies that Kant introduces this notion only in the third Critique).

${ }^{55}$ Other revealing descriptions are found in the Anthropology: "The endeavor to become conscious of one's representations is either the paying attention to (attentio) or the turning away from an idea of which I am conscious (abstractio). - The latter is not the mere failure and omission of the former ... but rather a real act of the cognitive faculty of stopping a representation of which I am conscious from being in connection with other representations in one consciousness" (Anthropology 7:131). And later: "To observe the various acts of representative power in myself, when I summon them, is indeed worth reflection; it is necessary and useful for logic and metaphysics" (Anthropology 7:133).
} 
claim that our minds have associative tendencies ${ }^{56}$ ). It is not just a method of performing thought experiments; rather, it is a matter of attending directly to certain features of one's own mind. For those reasons, this method does not fit easily with the methodology of contemporary analytic philosophy. ${ }^{57}$

Kant explicitly describes this method as a priori, even though the original aesthetic judgment had empirical elements. In loose terms, the reason Kant takes the method to be a priori seems to be that it uses a priori equipment to isolate a priori representations. Empirical representations can be involved, but their content does not inform the claim we reach on the basis of the method, since the method hinges on abstracting away from them. This is fundamentally different from what Kant does, say, in the Metaphysical Foundations of Natural Science, where the content of an "intrinsically empirical" representation (the concept of matter) plays a direct role in the relevant explanations (cf. Metaphysical Foundations 4:472).

Kant therefore thinks that there is an act of inner attention that justifies at least some claims concerning formal features of our minds. Since the form/matter contrast is ubiquitous in Kant's philosophy, and is often used in distinguishing the contribution of sensation from the other aspects of the mind (e.g. A20/B34), it is not surprising that it surfaces here. In any case, the act that reveals these formal features does not give us a deeper explanation of the relevant claims (it does not show us why our minds are the way they are), but it does justify us in making them. Such a method fits perfectly with the sort of statements we saw in the previous subsection: it is by this method that Kant could gain "exhaustive acquaintance" with reason (Axiv), that the mind could "become completely familiar with its own capacity" (B23), and how we might "inquire within pure reason itself" (Prolegomena 4:274). Since this method yields insight into certain aspects of the mind in a way reminiscent of traditional rationalism, ${ }^{58}$ but not into the mind's

\footnotetext{
${ }^{56} \mathrm{Cf}$. A100, where Kant describes the psychological law of association as "merely empirical," in contrast to the principles of synthesis he describes there.

${ }^{57}$ Kenneth Westphal claims that Kant's method is based on "epistemic reflection," which comes down to performing thought experiments (Westphal, "Epistemic Reflection," and Kant's Transcendental Proof of Realism). Westphal seems to think that this helps us avoid perplexity about whether Kant's judgments are analytic or synthetic ("Epistemic Reflection," 140), though he does not explain how the fact that a judgment is the result of a thought experiment would keep it from having one or the other status. Thought experiments are easiest to understand when they amount to conceptual analysis, but that does not seem to be Westphal's view ("Epistemic Reflection," 153; Kant's Transcendental Proof of Realism, 2).

${ }^{58}$ Leibniz also endorses reflection, though he takes it to reveal deeper facts than Kant does: "reflection is nothing but attention to what is within us ... In view of this, can it be denied that there is a great deal that is innate in our
} 
fundamental nature, I call it 'short-range rationalist reflection. ${ }^{, 59}$

Perhaps Kant's most plausible application of this method concerns space. Consider the following passage from the B Introduction:

Gradually remove from your experiential concept of a body everything that is empirical in it - the color, the hardness or softness, the weight, even the impenetrability - there still remains the space that was occupied by the body (which has now entirely disappeared), and you cannot leave that out ... Thus, convinced by the necessity with which this ... presses itself on you, you must concede that it has its seat in your faculty of cognition $a$ priori. (B5, cf. A24/B38-39, Prolegomena 4:283)

This description shows how robust Kant thinks the results of the reflection are. It is not merely that we abstract away from the some empirical elements of our representation of body and find that we are left with the representation of space. Rather, the representation of space presses itself on us with necessity. If that were an apt description of how the reflection goes, then it is plausible that we would thereby be justified in claiming that the representation was built into our faculty of cognition, and so was a priori. We would likewise be justified in claiming that we could have no other form of intuition (at least, none that was inconsistent with that of space).

With this characterization of short-range rationalist reflection in place, it becomes easy to find other places where Kant refers to it in the first Critique. ${ }^{60}$ Kant consistently talks of isolating

minds, since we are innate to ourselves ... and since we include Being, Unity, Substance, Duration, Change ... and hosts of other objects of our intellectual ideas? And since these objects are immediately related to our understanding and always present to it (although our distractions and needs prevent our being always aware of them), is it any wonder that we say that these ideas ... are innate in us?" (New Essays on Human Understanding, 51-52). In taking Kant to be advancing a modest form of rationalism, I agree with Karl Ameriks, though Ameriks' reasons for doing so are Kant's conclusions (in particular, Kant's conclusion that pure representations are necessary for experience, and an immaterialist ontology), not Kant's methodology. Ameriks thinks Kant's methodology just involves deducing necessary conditions for "common experience" (cf. Ameriks, Interpreting Kant's Critiques, 4-12). I think Ameriks gives us part of the right story here (cf. Marshall, "Kant's Metaphysics of the Self," 3).

59 The above passage from the third Critique suggests that this is a kind of abstraction. Kant also talks of abstraction as a step in the formation of concepts (see Logic 9:94). Whether Kant saw these sorts of abstraction as related is a question I cannot pursue here. Similarly, Houston Smit and Karin de Boer note that some form of reflection is involved in any cognition of an object (Smit "Role of Reflection," 213, de Boer, "Reason's Enlightenment," 62ff.). That is plausible, but the type of reflection I am interested in appears to be one that is used only in more philosophical moments (which is consistent with there being some pre-philosophical antecedent to it). Robert Hanna gives an account of analytic judgments that, if correct, would imply that similar reflective capacities are involved there as well (Hanna, "Kant's Answer").

${ }^{60}$ There is at least one precedent in the pre-Critical work. In $\$ 8$ of the 1770 Inaugural Dissertation, Kant describes (in a Cartesian/Leibnizian vein) how we arrive at the pure concepts: "the philosophy which contains the first principles of the use of the pure understanding is metaphysics ... the concepts met with in metaphysics are not to be 
features of our faculties by removing or abstracting away from the empirical aspects of our state.

Here are six relevant passages, with another six relegated to a footnote:

if one removes from our experiences everything that belongs to the senses, there still remain certain original concepts and the judgments generated from them, which must have arisen entirely a priori (A2)

even our experiential cognition is a composite of that which we receive through impressions and that which our own cognitive faculty ... provides out of itself, which addition we cannot distinguish from that fundamental material until long practice has made us attentive to it and skilled in separating it out (B1-2)

if you remove from your empirical concept of every object, whether corporeal or incorporeal, all those properties of which experience teaches you, you could still not take from it that by means of which you think of it as a substance or as dependent on a substance ... Thus, convinced by the necessity with which this concept presses itself on you, you must concede that it has its seat in your faculty of cognition a priori (B5-6)

The constant form of this receptivity, which we call sensibility, is a necessary condition of all the relation within which objects can be intuited as outside us, and, if one abstracts from these objects, it is a pure intuition, which bears the name of space (A27/B43)

In regard to appearances in general one cannot remove time, though one can very well take the appearances away from time. Time is therefore given a priori. In it alone is all actuality of appearances possible. The latter could all disappear, but time itself, as the universal condition of their possibility, cannot be removed. (A31/B46)

If we abstract from all content of a judgment in general, and attend only to the mere form of the understanding in it, we find that the function of thinking in that can be brought under four titles, each of which contains under itself three moments. They can be suitably be represented in the following table ... (A70/B95) ${ }^{61}$

sought in the senses but in the very nature of the pure understanding, and that not as innate concepts but as concepts abstracted from the laws inherent in the mind (by attending to its actions on the occasion of an experience)" (Dissertation 2:396, though see Inquiry 2:286 on "an immediate and self-evident inner consciousness").

${ }^{61}$ Cf. Prolegomena 4:323, with its talk of the "long reflection" required for establishing the table of categories and its relation to judgment. Also noteworthy is his explanation in $\$ 19$ of the B Deduction of how he reached his explanation of the nature of judgment, where he claims that he "investigated more closely" and "found" that judgments are the way to bring given cognitions to the objective unity of apperception (B141). In the Prolegomena, Kant states that "general yet nonetheless definite principles are not easily learned from others who have only had them floating obscurely before them. One must first have come to them oneself through one's own reflection, after which one also finds them elsewhere, where one certainly would not have found them before" (Prolegomena 4:270). See also Metaphysical Foundations 4:472 (“All true metaphysics is drawn from the faculty of thinking itself”). Such an abstracting procedure also seems to be behind the discussion in A305/B362ff., which leads Kant to conclude that "the proper principle of reason in general (in its logical use) is to find the unconditioned for conditioned cognitions of the understanding" (A307/B364 - cf. Smit, "Role of Reflection," 209-215). Finally, see Kant description of how we are aware of our freedom at Groundwork 4:462. 
These passages plausibly present Kant's justification for some of his basic claims about the mind. Many of Kant's readers have seen these passages as incomplete arguments, or as alternative ways of Kant expressing his conclusions. ${ }^{62}$ An alternative is that Kant does not say more because he thinks there is nothing more to be said. If one properly performs short-range rationalist reflection, one will simply come to see that certain formal representational features hold of our mind.

Kant also discusses such a procedure in other terms, sometimes just calling it "reflection" (cf. Anthropology 7:134n.). An instance of such reflection is "transcendental reflection." a sort of short-range rationalist reflection with a specific goal: determining which faculty representations belong to. This would seem to presuppose that one has already determined (by prior reflection) the essential structures of the relevant faculties. Kant describes it as follows:

The action through which I make the comparison of representations in general with the cognitive power in which they are situated, and through which I distinguish whether they are to be compared to one another as belonging to the pure understanding or to pure intuition, I call transcendental reflection. (A261/B317)

Transcendental reflection, which Kant claims "is a duty from which no one can escape if he would judge anything about things a priori” (A263/B319), would seem to be the basis for the claim that intuitions and concepts are fundamentally different. Importantly, it is an action, not some more basic claim.

What, then, is the "third thing" for these basic synthetic a priori claims? It would seem to be a state of awareness of our own minds. This awareness it not, I think, an intuition. Though Kant sometimes states that all synthetic a priori judgments have pure intuition as their third thing

\footnotetext{
${ }^{62}$ E.g. Guyer, Kant and the Claims of Knowledge, 347 argues that it is unclear whether the arguments about space and time are psychological or epistemological, but that there are problems either way. Lorne Falkenstein states that these arguments are "unworkably ambiguous," so that the most substantive assumptions of the argument have been left implicit (Falkenstein, Intuitionism, 189ff.).

${ }^{63}$ Westphal sees transcendental reflection as Kant's general method in the Critique, despite the fact that Kant's only explicit mention of it is in the Amphiboly chapter (see Kant's Transcendental Proof of Realism, Chapter 1). I think it is safer to see it as an instance of the more general sort of reflection on the mind Kant discusses elsewhere (something Westphal has reason to ignore, given his view that the bases of Kant's philosophy are well suited to strong claims of realism). That said, Kant's varied use of the term 'transcendental' makes it difficult to pin down how broadly he thinks transcendental reflection extends (cf. de Boer, "Reason's Enlightenment," 67).
} 
(cf. "On a Discovery" $8: 241^{64}$ ), this is typically in passages where he seems to be demanding explanation for all synthetic a priori judgments. I propose that the basic synthetic a priori claims which Kant implicitly sets aside in these passages neither demand explanation nor take intuition as their third thing. The awareness of the mind that justifies them is not easily placed in Kant's normal taxonomy of representation (it is immediate, and yet reveals general features of the faculties of all human minds as such, which seems to disqualify it from being either an intuition or a concept). Regardless, the passages I have quoted make it hard to deny that Kant thinks it is real and crucial to his philosophy. ${ }^{65}$

\section{Six objections and replies}

There are at least six potential objections to the above proposal. First: it might seem that I am suggesting that Kant thinks our minds are perfectly transparent to us. Any interpretation that suggested that would certainly be mistaken. Kant states that some representational capacities operate without our being fully aware of them. Synthesis, one of the key notions in the theoretical philosophy, is said to be "blind," and something of which we are "seldom even conscious" (A78/B103). In the Anthropology, Kant is quite explicit that "[ $\mathrm{t}]$ he field of sensuous intuitions and sensations of which we are not conscious ... is immense" (Anthropology 7:135). ${ }^{66}$ Second: Kant explicitly rejects the project of rational psychology, which attempts to discern features of the mind using rationalist methods (see A342/B400ff.), and that might appear to rule out any form of rationalist reflection. Third: Kant's Refutation of Idealism aims at showing that knowledge of the mind requires prior knowledge of outer objects, which seems to suggest that reflection on the mind cannot be philosophically fundamental. Fourth: one might worry about my

\footnotetext{
${ }^{64}$ In the Doctrine of Method, Kant says that the "third thing" transcendental logic considers is possible experience (A766/B794). How exactly we are supposed to base judgments on "possible experience" is not clear - surely, judgments must be based on something actual. But we can read this claim in line with my proposal: we base judgments on possible experience via our awareness of those faculties that make experience possible. As an analogy: one way of figuring out what sorts of paintings are possible is by examining actual painting equipment.

${ }^{65}$ Many of Kant's distinctions seem to break down when applied to pure representations. For instance, the forms of judgment and the schemata themselves are not easily classified as phenomenal or noumenal.

${ }^{66}$ Such passages are the reason why Pereboom (and others, I suspect) rejects the sort of line I am proposing. Pereboom seems to assume that rationalist introspection of any type would guarantee transparency (see Pereboom, "Kant on Justification, 41). See also Allais, "Kant's Argument for Idealism," 52.
} 
proposal because of Kant's explicit exclusion of introspection and empirical psychology from pure philosophy (cf. A848/B877). Fifth: it might seem like the deliverances of short-range rationalist reflection would be too limited to provide the basis for the major conclusions of the Critique. And sixth: the sort of self-knowledge provided by the reflection I have described may seem to violate Kant's epistemological strictures, for Kant insists that we have no cognition of how we are in ourselves. ${ }^{67}$

The first objection can be answered by recalling the description short-range rationalist reflection from the third Critique. There, Kant claims that the method allows us to discern certain formal features of our representational state. Nothing in the method implies it will reveal every formal feature of the mind, and the method will never itself reveal non-formal features. While synthesis, for instance, has an important connection to such formal features, synthesis itself is not a form, so Kant can consistently hold that we have limited access to it. Likewise, when Kant talks about unconscious representations in Anthropology 7:135, he describes them as "sensuous intuitions as sensations," which are exactly what makes up the material aspect of our representational state that short-range rationalist reflection is directed away from. The method is therefore far from full inner transparency. Moreover, nothing in the above passages implies that this method is easy. ${ }^{68}$ Kant thinks that the analysis of concepts can be extremely difficult (e.g. A728/B756ff.), even though that is clearly a priori. Short-range rationalist reflection, though a priori, might nonetheless be difficult; presumably, it is easier in aesthetic judgments, and more difficult in judgments about, say, the complete functions of judgment. ${ }^{69}$ Kant states in the Prolegomena that nobody before him answered the question of the possibility of the synthetic a priori because "a satisfactory answer to this one question requires more assiduous, deeper, and more painstaking reflection than the more prolix work of metaphysics ever did" (Prolegomena 4:277). Such difficulty does not threaten the epistemological directness of the method. As an analogy: it is not a challenge to a direct realist account of perception that it can at times take painful effort to blink the dirt out of one's eyes and to focus one's sight on an object.

\footnotetext{
${ }^{67}$ E.g. Bxxviii, B158, A278/B344, B409, and Groundwork 4:451.

${ }^{68}$ The quoted passage from B23 asserts that it is easy to determine the bounds of reason's use after we have become completely familiar with its capacity, but that is another matter.

${ }^{69}$ We know, in fact, that it took Kant some time to arrive at the table of judgments in the Critique (cf. Tonelli, "Die Voraussetzungen zur Kantischen Urteilstafel in der Logik des 18. Jahrhunderts").
} 
With regard to the second objection: whether our soul has the features claimed by rational psychology (of being a substance, simple, identical, etc.) is not something that acquaintance with formal features of our representational state would reveal - indeed, this may be the main point of the Paralogisms chapter (cf. B421-22). ${ }^{70}$ The inner nature of the thinking subject remains undecided by the formal features of the mind. A similar point bears on the Refutation (the subject of the third objection): the insights this reflection provides are less than the "empirically determined consciousness of my own existence" (B275) that Kant thinks presupposes experience of outer objects.

Fourth, Kant's exclusion of introspection and empirical psychology from critical philosophy can be explained by the fact that both are necessarily concerned with the material of representation that results from our being affected. Inner sense is that "by means of which the mind intuits itself" (A22/B37), and this hinges on "the way in which the mind is affected through its own activity" (B67). Yet basic formal features of the mind do not hinge on how the mind affects itself, so a means of accessing such features would not count as inner sense. ${ }^{71}$ Kant's excluding inner sense and empirical psychology from his methodology does not amount to excluding any sort of "inner turn.",72

Fifth, my proposal does imply that any of Kant's major conclusions directly follow from the results of reflection. For one, a number of analytic judgments are surely involved in Kant's explanations. For another, Kant may well rely on some inferences to the best explanation and employ suppositional or holistic reasoning. Moreover, though it would move us back toward the Regress Puzzle, there is nothing stopping a determined advocate of approach (b) (which holds that some of Kant's basic claims are empirical) from also granting reflection a role. The facevalue reading of the texts in the previous sub-section does not suggest that the method I have described is the only method Kant employs or needs to employ in his critical philosophy. Whether this is so can only be decided by a more detailed investigation of Kant's arguments than I can provide here.

\footnotetext{
${ }^{70}$ See Marshall, "Kant's Metaphysics of the Self," 6-7.

${ }^{71}$ For a careful study of Kant's theory of inner sense that supports this line, see Stéphane Dirschauer, "La Théorie Kantienne de L'Auto-Affection."

${ }^{72}$ Westphal, "Epistemic Reflection," 141-42 similarly argues that Kant's rejection of introspection is not the rejection of all self-directed reflection. Longuenesse claims that transcendental reflection "is not an introspective procedure at all" (Longuenesse, Capacity to Judge, 114), though it is unclear how she thinks such reflection works.
} 
The sixth and final objection was that the proposal is inconsistent with Kant's insistence that we have no cognition of ourselves as we are in ourselves. This objection is strongest if we take Kant to be insisting that I have no knowledge of any non-empirical facts about myself. Though such a strict reading of Kant's epistemological strictures was once prevalent, however, a number of recent commentators have shown that there are strong textual and philosophical grounds for more permissive readings. ${ }^{73}$ Since I cannot enter into the details of those discussions here, I will instead just note some reasons for saying that the results of short-range rationalist reflection would neither (I) concern the self as it is in itself, nor (II) count as cognition. On (I): all the explanatorily basic claims I have focused on (e.g. that we have only space and time as the forms of our intuition) concern how our mind relates to objects in representing them (cf. A38/B55, B158n.). If, as several commentators have proposed (see the previous note), the "in itself' is at least partly meant as a contrast to the relational, then features of how the mind relates to objects would not be aspects of the mind as it is in itself. Concerning (II): in a number of places, Kant claims that cognition (Erkenntnis) is a sort of "determinate" representation (e.g. B137, Prolegomena 4:315). In his discussion of matter and form in the Amphiboly chapter, however, Kant states that determinate representation requires both matter and form (A266/B322ff.). Awareness or knowledge of just the formal features of our mind, then, could not count as cognition. ${ }^{74}$ Similarly, at B137 Kant claims that cognitions "consist in the determinate relation of given representations to an object." The "given representations" here are presumably intuitions (and not just the pure intuitions of space and time). In that case, an epistemic state (even one we today would count as knowledge) that did not involve intuitions would not count as cognition. If either of these points concerning (I) and (II) are correct (and I do not claim to have given conclusive arguments here), then the reflection I have described would not provide us with cognition of ourselves as we are in ourselves.

\footnotetext{
${ }^{73}$ For instance: Warren, Reality and Impenetrability, Adams, "Things in Themselves," Langton, Kantian Humility, Smit, "Role of Reflection," and Hogan, "How to Know Unknowable Things in Themselves." For relevant but more isolated discussions, see also Beiser, German Idealism, 158, Ameriks, Interpreting Kant's Critiques, 17, Allais, "One World," 679, Wuerth, "Kant's Immediatism, Pre-Critique," 515ff., and Wuerth, "The Paralogisms of Pure Reason," 211ff. Smit's discussion is especially conducive to the present argument, since he is directly concerned with the permissibility of gaining knowledge of our own faculties through reflection, and places a similar emphasis on form.

${ }^{74} \mathrm{Cf}$. $\$ 25$ of the B Deduction: "I exist as an intelligence that is merely conscious of its faculty for combination" (B158), which is contrasted with self-cognition. The proposal that cognition is different from knowledge is not new. See, e.g., Adams, “Things in Themselves," 807.
} 
In sum: while short-range rationalist reflection is a source of justification for claims about the essence of our thinking faculties, it is more limited than other sorts of insight in the mind that philosophers have claimed (e.g. Descartes). At the same time, many philosophers would deny we have even such a modest capacity (e.g. Hume), or if they accepted it, might conclude that it yields different conclusions from what Kant thought (e.g. Schopenhauer). If we today reject the idea of any such capacity (and I do not think it is clear we should), then it may seem uncharitable to ascribe it to Kant. If so, that would be a point against interpretation (c). But as we have seen, the textual case for this interpretation is very substantial, it ascribes to Kant a consistent methodology, and the alternative interpretations face more serious problems. Despite having some potential costs, (c) is the best solution to the Regress Puzzle.

\section{Conclusion}

I conclude by summarizing my overall interpretive proposal, and by addressing one final question. On my reading, Kant thinks that some synthetic a priori claims about (purportedly) representation-independent objects can be successfully explained on the basis of certain claims about the mind. These latter claims are themselves synthetic and priori, and no further explanation is given for them. Nonetheless, Kant sees these explanations as satisfactory, since they solve the Distance Problem. He believes that he is entitled to make these claims via the method of short-range rationalist reflection, which yields knowledge of the formal features of the mind (but not cognition of the mind in itself).

The answer to the question posed in the title of this paper, therefore, is negative: Kant does not demand explanation for all synthetic a priori claims. This conclusion raises the question of why Kant describes his project in a way that has suggests that he does make the general demand. I offer the following conjecture: for Kant, the most pressing epistemological concern is the Distance Problem, and short-range rationalist reflection struck him as unproblematic. So when he asks how synthetic a priori judgments are possible, there is an implicit restriction that he thinks is obvious. The restriction is to puzzling a priori synthetic claims, as defined by the Distance Problem. Since Kant thinks that restriction is obvious, he does always not spell it out 
(though cf. Prolegomena 4:296). If so, this was an unfortunate presentational choice. Once we see the method behind Kant's project, we might consider how he might have presented it better (e.g. by defining 'synthetic' differently), but that issue is more literary than philosophical.

Still, if we accept the present proposal, there are further philosophically substantive questions to be answered about Kant's project. More clarity is certainly needed concerning Kant's doctrine of the limits of our cognition. Moreover, we should assess just how uncharitable it is to attribute the methodology of short-range rationalist reflection to Kant. If Kant relies on such reflection, then there is perhaps less argument in the Critique than we might have thought, and more insistence on a certain way of attending to oneself. On my reading, Kant is at least as much a phenomenologist as an analytic philosopher. If the argument I have given here is right, that should not dissuade any of Kant's readers from understanding his project in the way I have described. The very intelligibility of his philosophical project may turn on it. $^{75}$

\footnotetext{
${ }^{75}$ For comments and discussion, I am grateful to Eli Alshanetsky, Ralf Bader, David James Barnett, Andrew Chignell, Katherine Dunlop, Raphaël Ehrsam, Kit Fine, Don Garrett, Scott Jenkins, Béatrice Longuenesse, John Morrison, Tyke Nunez, Erick Rabin, Mike Raven, Elliot Paul, Jeff Russell, Karl Schafer, Jonathan Simon, the audience at the 2010 Eastern APA NAKS session, and two referees for JHP.
} 
Works Cited

Adams, Robert M. "Things In Themselves.” Philosophy and Phenomenological Research 57 (1997): 801-825.

Allais, Lucy. 'Kant's Argument for Transcendental Idealism in the Transcendental Aesthetic." Proceedings of the Aristotelian Society 110 (2010): 47-75. ["Kant's Argument for Idealism"]

Allais, Lucy. "Kant's One World: Interpreting 'Transcendental Idealism'.” British Journal for the History of Philosophy 12 (2004): 655-84. [“One World”]

Allison, Henry. Kant's Transcendental Idealism (2 ${ }^{\text {nd }}$ ed.). New Haven: Yale University Press, 2004.

Allison, Henry. Idealism and Freedom: Essays on Kant's Theoretical and Practical Philosophy. Cambridge: Cambridge University Press, 1996. [Idealism and Freedom]

Ameriks, Karl. Interpreting Kant's Critiques. Oxford: Oxford University Press, 2003.

Ameriks, Karl. "Kant's Transcendental Deduction as a Regressive Argument.” KantStudien 69 (1978): 273-87. [“Regressive Argument”]

Anderson, Lanier. “The Wolffian Paradigm and its Discontents: Kant's Containment Definition of Analyticity in Historical Context." Archiv für Geschichte der Philosophie 87 (2005): 22-74. [“Wolffian Paradigm”]

Ayer, A.J. Language, Truth and Logic. London: Gollancz, 1953. 
Beck, Lewis White. Essays on Kant and Hume. New Haven: Yale University Press, 1978.

Beck, Lewis White. A Commentary on Kant's Critique of Practical Reason. Chicago: University of Chicago Press, 1960. [Commentary]

Beiser, Frederick. German Idealism: The Struggle against Subjectivism, 1871-1801. Cambridge: Harvard University Press, 2002. [German Idealism]

Beiser, Frederick. The Fate of Reason: German Philosophy from Kant to Fichte. Cambridge: Harvard University Press, 1987. [Fate of Reason]

Bencivenga, Ermanno. Kant's Copernican Revolution. Oxford: Oxford University Press, 1987.

Bennett, Jonathan. Kant's Analytic. Cambridge: Cambridge University Press, 1966.

BonJour, Laurence. In Defense of Pure Reason. Cambridge: Cambridge University Press, 1998.

Brook, Andrew. "Kant's View of the Mind and Consciousness of Self." In Edward N. Zalta (ed.), The Stanford Encyclopedia of Philosophy (Winter 2011 Edition). URL = <http://plato.stanford.edu/archives/win2011/entries/kant-mind/>.

de Boer, Karin. “Pure Reason's Enlightenment: Transcendental Reflection in Kant's first Critique.” Kant Yearbook 2010: 53-73. [“Reason's Enlightenment”]

Devitt, Michael. "There is no A Priori." In Steup and Sosa, Contemporary Debates in Epistemology, 105-114. 
Dicker, Georges. Kant's Theory of Knowledge: An Analytical Introduction. Oxford: Oxford University Press, 2004. [Kant's Theory]

Dirschauer, Stéphane. "La Théorie Kantienne de L'auto-affection,” Kant-Studien 95 (2004): 53-85.

Falkenstein, Lorne. Kant's Intuitionism: A Commentary on the Transcendental Aesthetic. Toronto: University of Toronto Press, 1995. [Intuitionism]

Fichte, Johann. Foundations of Transcendental Philosophy. Edited by D. Breazeale. Ithaca: Cornell University Press, 1992. [Foundations]

Förster, Eckart, ed. Kant's Transcendental Deductions. Stanford: Stanford University Press, 1989.

Forster, Michael N. Kant and Skepticism. Princeton: Princeton University Press, 2008.

Friedman, Michael. Kant and the Exact Sciences. Cambridge: Harvard University Press, 1992. [Exact Sciences]

Goldman, Avery. "Critique and the Mind: Towards a Defense of Kant's Transcendental Method." Kant Studien 98 (2007): 403-417. [“Critique and the Mind”]

Guyer, Paul, ed.. The Cambridge Companion to Kant's Critique of Pure Reason. Cambridge: Cambridge University Press, 2010.

Guyer, Paul. "The Transcendental Deduction of the Categories." In Guyer, The Cambridge Companion to Kant, 123-160. 
Guyer, Paul, ed. The Cambridge Companion to Kant. Cambridge: Cambridge University Press, 1992.

Guyer, Paul. Kant and the Claims of Knowledge. Cambridge: Cambridge University Press, 1987.

Hanna, Robert. "How Do We Know Necessary Truths? Kant's Answer," European Journal of Philosophy 6 (1998): 115-145. [“Kant's Answer”]

Hatfield, Gary "Empirical, Rational, and Transcendental Psychology: Psychology as Science and as Philosophy." in Guyer, The Cambridge Companion to Kant, 200-27.

Hogan, Desmond. "How to Know Unknowable Things in Themselves," Nous 43 (2009): 49-63.

Kant, Immanuel. Kants Gesammelte Schriften. Edited by the German Academy of Sciences. Berlin: De Gruyter, 1900-. [AA]

Kant, Immanuel. New Elucidation of the First Principles of Metaphysical Cognition. In Walford and Meerbote, Theoretical Philosophy 1755-1770, 1-45. [New Elucidation]

Kant, Immanuel. Inquiry Concerning the Distinctness of the Principles of Natural Theology and Morality. In Walford and Meerbote, Theoretical Philosophy 1755-1770, 243-285. [Inquiry]

Kant, Immanuel. On the Form and Principles of the Sensible and the Intelligible World. In Walford and Meerbote, Theoretical Philosophy 1755-1770, 373-415. [Dissertation]

Kant, Immanuel. Theoretical Philosophy 1755-1770. Edited and translated by David 
Walford and Ralf Meerbote. Cambridge: Cambridge University Press, 1992.

Kant, Immanuel. Critique of Pure Reason. Edited and translated by Paul Guyer and Allen Wood. Cambridge: Cambridge University Press, 1997.

Kant, Immanuel. Prolegomena to Any Future Metaphysics. Edited and translated by Gary Hatfield. Cambridge: Cambridge University Press, 2001. [Prolegomena]

Kant, Immanuel. Groundwork for the Metaphysics of Morals. In Gregor, Practical Philosophy, 37-107. [Groundwork]

Kant, Immanuel. Critique of Practical Reason. In Gregor, Practical Philosophy, 173-271. [Practical Reason]

Kant, Immanuel. Practical Philosophy. Edited and translated by Mary Gregor. Cambridge: Cambridge University Press, 1996.

Kant, Immanuel. Critique of the Power of Judgment. Edited and translated by Paul Guyer and Eric Matthews. Cambridge: Cambridge University Press, 2000. [Judgment]

Kant, Immanuel. Anthropology from a Pragmatic Point of View. Edited and translated by Robert B. Louden. Cambridge: Cambridge University Press, 2006. [Anthropology]

Kant, Immanuel. Lectures on Metaphysics. Edited and translated by Karl Ameriks and Steve Naragon. Cambridge: Cambridge University Press, 1997. [Metaphysics]

Kant, Immanuel. Lectures on Logic. Edited and translated by J. Michael Young. Cambridge: Cambridge University Press, 1992. [Logic] 
Kant, Immanuel. Correspondence. Edited and translated by Arnulf Zweig. Cambridge: Cambridge University Press, 1999.

Kant, Immanuel. Metaphysical Foundations of Natural Science. In In Allison and Heath, Theoretical Philosophy after 1781, 171-269. [Metaphysical Foundations]

Kant, Immanuel. "On a Discovery whereby any New Critique of Pure Reason is Made Superfluous by an Older One.” Translated by Henry Allison. In Allison and Heath, Theoretical Philosophy after 1781, 271-335.

Kant, Immanuel. "What Real Progress has Metaphysics made in Germany since the time of Leibniz and Wolff?" In Allison and Heath, Theoretical Philosophy after 1781, 337423. [“What Real Progress?”]

Kant, Immanuel. Theoretical Philosophy after 1781. Edited by Henry Allison and Peter Heath. Cambridge: Cambridge University Press, 2002.

Kaulbach, Friedrich, and Ritter, Joachim, eds. Kritik und Metaphysik. Heinz Heimsoeth zum achtzigsten Geburtstag. Berlin: De Gruyter, 1966.

Kitcher, Patricia. Kant's Transcendental Psychology. Oxford: Oxford University Press, 1994.

Kitcher, Patricia. "Revisiting Kant's Epistemology: Skepticism, Apriority, and Psychologism.” Nous 29 (1995): 285-315. [“Revisiting Kant’s Epistemology”]

Kitcher, Philip. “A Priori Knowledge.” Philosophical Review 89 (1980): 3-23.

Kolb, Daniel. "Thought and Intuition in Kant's Critical System." Journal of the History 
of Philosophy 24 (1986): 223-41.

Langton, Rae. Kantian Humility. Oxford: Oxford University Press, 1998.

Lee, Seung-Kee. "The synthetic a priori in Kant and German idealism." Archiv für Geschichte der Philosophie 91 (2009): 288-329.

Leibniz, G.W. Philosophical Essays. Edited and translated by Roger Ariew and Daniel Garber. Indianapolis: Hackett Press, 1989.

Leibniz, G.W. New Essays on Human Understanding. Edited and translated by Peter Remnant and Jonathan Bennett. Cambridge: Cambridge University Press, 1996.

Longuenesse, Béatrice. Kant and the Capacity to Judge. Princeton: Princeton University Press, 1998. [Capacity to Judge]

Marshall, Colin. "Kant's Metaphysics of the Self.” Philosophers' Imprint 10 (2010): 121.

Merritt, Melissa. "Analysis in the Critique of Pure Reason." Kantian Review 12 (2006): 60-88.

Moore, G. E. "Kant's Idealism.” Proceedings of the Aristotelian Society, New Series 4 (1903): 127-140.

Nietzsche, Friedrich. Beyond Good and Evil. Edited and translated by Walter Kaufman. New York: Vintage Books, 1966.

Palmer, Linda. "On the Necessity of Beauty.” Kant-Studien 102 (2011): 350-66. 
Pereboom, Derk. "Self-Understanding in Kant's Transcendental Deduction.” Synthese 103 (1995): 1-42.

Pereboom, Derk. “Is Kant's Transcendental Philosophy Inconsistent?” History of Philosophy Quarterly 8 (1991): 357-72.

Pereboom, Derk. "Kant on Justification in Transcendental Philosophy." Synthese 85 (1990): 25-54. [“Kant on Justification”]

Proops, Ian. "Kant's Conception of Analytic Judgment." Philosophy and Phenomenological Research 70 (2005): 588-612.

Reich, Klaus. The Completeness of Kant's Table of Judgments. Stanford: Stanford University Press, 1992 (originally 1932). [Completeness]

Rosenberg, Jay. "Transcendental Arguments Revisited." Journal of Philosophy 75 (1975): 611-24.

Smit, Houston. "The Role of Reflection in Kant's Critique of Pure Reason." Pacific Philosophical Quarterly 80 (1999): 203-223. [“Role of Reflection”]

Steup, Mattias and Sosa, Ernest, eds. Contemporary Debates in Epistemology. Oxford: Blackwell Publishing, 2005

Strawson, P. F. "Sensibility, Understanding, and the Doctrine of Synthesis: Comments on Henrich and Guyer.” In Förster, Kant's Transcendental Deductions, 69-77. ["Sensibility"] 
Strawson, P. F. The Bounds of Sense. London: Methuen and Co., 1996. [Bounds]

Stroud, Barry. "The synthetic a priori in Strawson's Kantianism.” In Stroud, Understanding Human Knowledge: Philosophical Essays, 224-43.

Stroud, Barry. "Kantian Arguments, Conceptual Capacities, and Invulnerability.” In Stroud, Understanding Human Knowledge: Philosophical Essays, 155-76. ["Kantian Arguments"]

Stroud, Barry. Understanding Human Knowledge: Philosophical Essays. Oxford: Oxford University Press, 2000.

Tonelli, Giorgio. "Die Voraussetzungen zur Kantischen Urteilstafel in der Logik des 18. Jahrhunderts." In Kaulbach and Ritter, Kritik und Metaphysik. Heinz Heimsoeth zum achtzigsten Geburtstag, 134-156.

Warren, Daniel. Reality and Impenetrability in Kant's Philosophy of Nature. New York: Routledge, 2001. [Reality and Impenetrability]

Waxman, Wayne. Kant's Model of the Mind: A New Interpretation. New York: Oxford University Press, 1991. [Kant's Model]

Westphal, Kenneth. "Epistemic Reflection and Cognitive Reference in Kant's Transcendental Response to Scepticism." Kant-Studien 94 (2003):135-71. ["Epistemic Reflection"]

Westphal, Kenneth. Kant's Transcendental Proof of Realism. Cambridge: Cambridge University Press, 2004. 
Wolff, Christian. Vernünftige Gedanken von Gott, der Welt und der Seele des Menschen, auch allen Dingen überhaupt. Halle, 1732. [Vernünftige Gedanken]

Wolff, Christian. Philosophia prima sive ontologia methodo scientifica pertractata qua omnis cognitionis humanae principia continentur. Frankfurt, 1730. [Philosophia prima]

Wuerth, Julian. "Kant's Immediatism, Pre-Critique." Journal of the History of Philosophy 44 (2006): 489-532.

Wuerth, Julian. “The Paralogisms of Pure Reason.” In Guyer, The Cambridge Companion to Kant's Critique of Pure Reason, 210-44. 